\title{
Efficacy of Novel Fungicides against Purple Blotch in Onion (Allium cepa L.) in the Western Undulating Zone of Odisha, India
}

\author{
Niranjan Mandi*, Bhabani Shankar Nayak, Bibhuti Bhusan Sahoo, \\ Ganesh Prasad and Chandramani Khanda
}

\author{
All India Coordinated Research Project on Cotton, \\ Regional Research and Technology Transfer Station (OUAT), \\ Bhawanipatna, Kalahandi, Odisha-766001, India
}

*Corresponding author

Keywords

Onion, Purple blotch, Bulb yield, Fungicide,

Percentage Diseases Index (PDI)

\section{Article Info}

\section{Accepted:}

15 March 2020 Available Online: 10 April 2020

\section{A B S T R A C T}

\begin{abstract}
A field experiment was conducted to assess the effect of novel fungicides against the purple blotch disease in onion during Rabi 2016-17 and 2017-18 at the Regional Research and Technology Transfer Station (OUAT), Bhawanipatna in the Western Undulating Zone of Odisha. The experiment was laid out in randomized block design with eight treatments in three replications. The treatment combinations consist of seed treating chemical (Vitavax power) along with the new fungicides against the purple blotch in onion. The percentage diseases index (PDI) of purple blotch in onion varied from $28.67 \%$ to $65.33 \%$. Seed treatment with Vitavax power @ $0.2 \%$ along with foliar application of Tebuconazol 25 EC @ $1 \mathrm{ml} \mathrm{l}^{-1}$ was most effective in reducing the PDI $(28.67 \%)$ which was at par with Azoxystrobin 23 SC @ $1 \mathrm{ml} \mathrm{l}^{-1}$ with PDI of $31.33 \%$. Similarly, application of Difenoconazole 25 EC @ $0.6 \mathrm{ml} \mathrm{l}^{-1}$ with PDI of $41.33 \%$ was followed by Mancozeb 75 WG@ $2.5 \mathrm{~g} \mathrm{l}^{-1}$ with PDI of $43.33 \%$ as compared to control (65.33\%). Maximum disease control was recorded in Tebuconazol 25 EC @ $1 \mathrm{ml} \mathrm{l}^{-1}$ with PDC of $56.12 \%$ which was followed by Azoxystrobin 23SC @ 1 $\mathrm{ml}^{-1}$ with 52.04\%, Difenoconazole 25EC @ 0.6 $\mathrm{ml} \mathrm{l}^{-1}$ with $36.74 \%$. Maximum bulb yield (145.8 q ha ${ }^{-1}$ ) was recorded in Tebuconazol 25 EC@1 $\mathrm{ml} \mathrm{l}^{-1}$ which was statistically at par with Azoxystrobin $23 \mathrm{SC} @ 1 \mathrm{ml} \mathrm{l}^{-1}$ with 143.3 $\mathrm{q} \mathrm{ha}^{-1}$. The minimum bulb yield of $76.1 \mathrm{q} \mathrm{ha}^{-1}$ was recorded in control plot. The increase in bulb yield in Tebuconazol $25 \mathrm{EC} @ 1 \mathrm{ml} \mathrm{l}^{-1}$ was $91.59 \%$ over the control. Tebuconazol 25 EC @ $1 \mathrm{ml} \mathrm{l}^{-1}$ recorded the maximum B:C ratio (3.22) followed by Azoxystrobin 23 SC @ $1 \mathrm{ml} \mathrm{l}^{-1}$ with 3.14 .
\end{abstract}

\section{Introduction}

Onion (Allium cepa L.) is one of the most important horticultural crops grown worldwide and typically used as a spicy ingredient of both vegetarian and nonvegetarian dishes. The therapeutic uses of onion add value to its importance. The total area under onion in the world was 5.04 million ha with a production of 96.8 million tonnes and productivity of 19.2 tonnes $\mathrm{ha}^{-1}$, whereas in India the area under this crop was 1.31 million ha with a production of 22.1 million tonnes and productivity of 16.87 
tonnes $\mathrm{ha}^{-1}$ (FAOSTAT, 2018). During the year 2013-14, the area under onion in Odisha was 0.035 million ha with a production of 0.43 million tonnes and productivity of 12.28 tonnes ha ${ }^{-1}$ (Odisha Agriculture Statistics, 2013-14). Hence, there is a wide gap in productivity of this crop in Odisha as compared to the country and the world. This efficiency of onion production is mostly dependent upon the adequate agronomic practices and plant protection measures adopted during the cropping season. Schwartz and Mohan, 2008 documented that the decrease in yield in onion is caused by around 66 diseases. According to Gupta et al., (1994), 36 diseases are prevailing in India including 29 fungal, 3 viral and 4 bacterial diseases. Diseases like purple blotch, Stemphylium-blight and anthracnose are the most important bottlenecks for commercial cultivation of onion. Yadav et al., 2013 reported that around $80 \%$ yield loss of onion in India is caused by purple blotch disease Alternaria porri (Ellis) Cif. Seed treatment with fungicides like cabendazim, mancozeb, thiram and vitavax is one of the most important practices adopted as a precaution measure to protect the crop from fungal infection in the very early stage of the crop growth. Apart from that foliar spray of fungicides like Mancozeb, Difenoconazole, Hexaconazole, Propiconazole, Tebuconazole and Azoxystrobin is the cheapest tool to protect the crop from this disease. But very often it has been observed that the favorable environment promote the fungal growth and the injudicious application of plant protection chemicals increase the production cost. In such cases, the occurrence of diseases may be due to the presence of host-pathogen in seeds as well as in soil. Hence, seed treatment is important to protect the crop. Keeping this in mind the present experiment was conducted to find out the efficacy of fungicides for the control of purple blotch disease in onion.

\section{Materials and Methods}

The field experiment was conducted to assess the effect of novel fungicides against the purple blotch disease of onion during rabi 2016-17 and 2017-18 at the Regional Research and Technology Transfer Station (OUAT), Bhawanipatna, in the western undulating zone of Odisha. The experiment was laid out in randomized block design having eight treatment combinations including control in three replications. The details of the treatment combinations are as follows:

$\mathrm{T}_{1}$ : Seed treatment with Vitavax power @ $0.2 \%$.

$\mathrm{T}_{2}$ : Seed treatment with Vitavax power @ $0.2 \%$ + Azoxystrobin 23 SC @ $1 \mathrm{ml} \mathrm{l}^{-1}$

$\mathrm{T}_{3}$ : Seed treatment with Vitavax power @ $0.2 \%$ + Tebuconazole 25 EC @ $1 \mathrm{ml} \mathrm{l}^{-1}$

$\mathrm{T}_{4}$ : Seed treatment with Vitavax power @ $0.2 \%$ + Propiconazole 25 EC @ $1 \mathrm{ml} \mathrm{l}^{-1}$

$\mathrm{T}_{5}$ : Seed treatment with Vitavax power @ $0.2 \%$ + Hexaconazole 5 EC @ $2 \mathrm{ml} \mathrm{l}^{-1}$

$\mathrm{T}_{6}$ : Seed treatment with Vitavax power @0.2\% + Difenoconazole 25 EC @0.6 ml 1 ${ }^{-1}$ $\mathrm{T}_{7}$ : Seed treatment with Vitavax power @ $0.2 \%$ + Mancozeb 75 WP @ $2.5 \mathrm{~g} \mathrm{l}^{-1}$

$\mathrm{T}_{8}$ : Control (No chemical treatment)

Seedlings were raised in well prepared nursery bed. Eight weeks old seedlings of variety N-53 were manually transplanted with a spacing of $15 \mathrm{~cm} \times 10 \mathrm{~cm}$. Soon after transplanting, light irrigation was provided for the quick establishment of the seedlings. All other recommended package of practices were uniformly adopted to obtain the maximum bulb yield as per the treatment. The rainfall received during the crop season during the year 2016-17 and 2017-18 was $89.0 \mathrm{~mm}$ and $27.4 \mathrm{~mm}$, the mean maximum was 35.5 and $33.2{ }^{\circ} \mathrm{C}$ and the mean minimum temperature was 17.3 and $17.9{ }^{\circ} \mathrm{C}$ and the mean maximum was $65.4 \%$ and $54.8 \%$ and the mean 
minimum relative humidity was $48.4 \%$ and $45.6 \%$, respectively. Three sprays of different chemicals as per the treatment were given at 10 days interval starting from appearance of the disease. Observations on percentage disease index (PDI) were recorded from 10 randomly selected plants by using 0-5 point scale derived by Shrama, 1986. The details of the $0-5$ point scale are as follows.

0- No disease symptom

1- A few spots towards the tip covering less than $10 \%$ of the leaf area.

2- Several dark purplish-brown patches covering less than $20 \%$ of leaf area.

3- Several patches with paler outer zone covering up to $40 \%$ of leaf area.

4- Long streak covering up to $75 \%$ of leaf area or breaking of the leaves from the center.

5- Complete drying of the leaves or breaking of the leaves from the base.

PDI was calculated using the following formula derived by Wheeler (1969). The percentage value was transformed and subjected to statistical analysis.

$\mathrm{PDI}=$

Sum of the individual disease

ratings
Total number of Maximum
plants assessed X disease rating

The percentage of disease control (PDC) was calculated by using the following formula given by Chester, 1959.

$\mathrm{PDC}=$

PDI in control plot - PDI in treated plot PDI in control plot

\section{Results and Discussion}

The data presented in Table- 1 and depicted in Figure 1 revealed that all the fungicidal treatments were significantly superior to the untreated check (control) in reducing the disease severity and increasing the bulb yield.

There was significant variation in PDI, PDC and bulb yield in onion due to the effect of seed treatment with vitavax power and the foliar application of different fungicides. The PDI of purple blotch in onion varied from $28.67 \%$ to $65.33 \%$. Seed treatments with vitavax power @ $0.2 \%$ were uniformly adopted in all treatment combinations except the control, which expressed its considerable effect to control the disease incidence during the cropping period. However, the variation in PDI was due to the effect of different fungicides as foliar spray.

Foliar application of Tebuconazol 25 EC @ 1 $\mathrm{ml} \mathrm{l}^{-1}$ was most effective in reducing the PDI $(28.67 \%)$ which was at par with application of Azoxystrobin 23SC @ $1 \mathrm{ml} \mathrm{l}^{-1}$ with 31.33 \% PDI. Application of Difenoconazole 25 EC @ $0.6 \mathrm{ml} \mathrm{l}^{-1}$ resulted in PDI of $41.33 \%$, which was followed by Mancozeb 75 WG @ $2.5 \mathrm{~g} \mathrm{l}^{-}$ ${ }^{1}$ with $43.33 \%$ and Propiconazole 25 EC @ 1 $\mathrm{ml} \mathrm{l}^{-1}$ with $44.00 \%$ as compared to control with a PDI of $65.33 \%$. Maximum disease control was recorded in plots treated with Tebuconazol 25 EC @ $1 \mathrm{ml} \mathrm{l}^{-1}$ with PDC of $56.12 \%$, which was followed by Azoxystrobin 23 SC@1 $@ \mathrm{ml} \mathrm{l}^{-1}(52.04 \%)$, Difenoconazole 25 EC@0.6 $\mathrm{ml} \mathrm{l}^{-1}(36.74 \%)$ and Mancozeb 75 WP @ $2.5 \mathrm{~g} \mathrm{l}^{-1}(33.17 \%)$.

The yield data revealed that there was significant effect of fungicidal treatments on bulb yield (Table 1). 
Table.1 Effect on different fungicides on purple blotch in onion under western undulating zone of Odisha (Pooled data of two years)

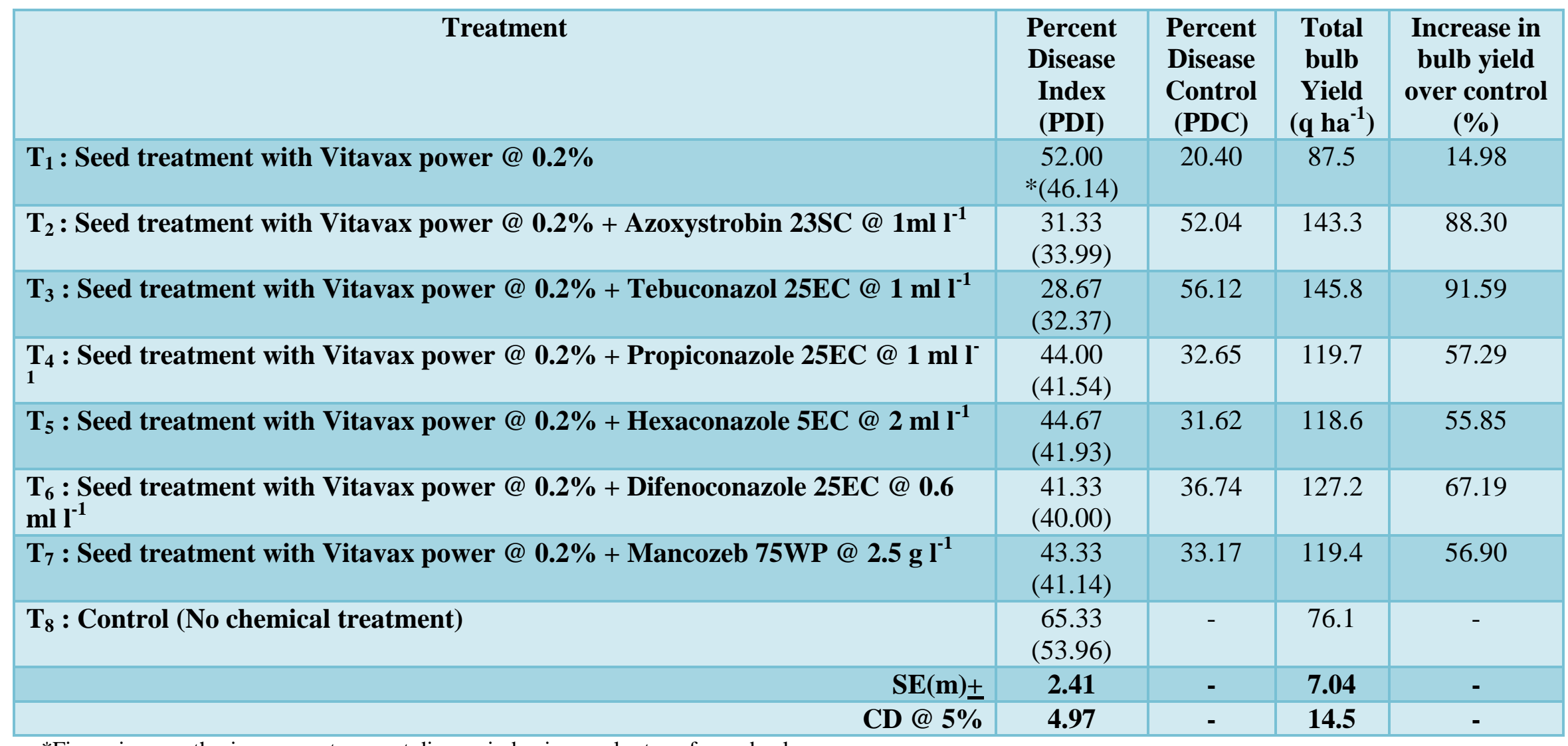

*Figure in parenthesis represent percent disease index in angular transformed value 
Table.2 Economics of different fungicidal treatments

\begin{tabular}{|c|c|c|c|c|}
\hline Treatment & $\begin{array}{c}\text { Cost of } \\
\text { cultivation } \\
\text { (Rs.) }\end{array}$ & $\begin{array}{c}\text { Gross } \\
\text { return } \\
\text { (Rs.) }\end{array}$ & $\begin{array}{c}\text { Net } \\
\text { return } \\
\text { (Rs.) }\end{array}$ & $\begin{array}{l}\text { B:C } \\
\text { ratio }\end{array}$ \\
\hline $\mathrm{T}_{1}$ : Seed treatment with Vitavax power @ $0.2 \%$ & 82000 & 175000 & 93000 & 2.13 \\
\hline $\begin{array}{l}\mathrm{T}_{2} \text { : Seed treatment with Vitavax power @ 0.2\% } \\
+ \text { Azoxystrobin 23SC @ 1ml I I }\end{array}$ & 91200 & 286600 & 195400 & 3.14 \\
\hline $\begin{array}{l}T_{3} \text { : Seed treatment with Vitavax power @ } 0.2 \% \\
+ \text { Tebuconazol 25EC @ } 1 \mathrm{ml} \mathrm{l}^{-1}\end{array}$ & 90500 & 291600 & 201100 & 3.22 \\
\hline $\begin{array}{l}\mathrm{T}_{4} \text { : Seed treatment with Vitavax power @ } 0.2 \% \\
+ \text { Propiconazole 25EC @ } 1 \mathrm{ml} \mathrm{l}^{-1}\end{array}$ & 88000 & 239400 & 151400 & 2.72 \\
\hline $\begin{array}{l}\mathrm{T}_{5} \text { : Seed treatment with Vitavax power @ } 0.2 \% \\
+ \text { Hexaconazole 5EC @ } 2 \mathrm{ml} \mathrm{l}^{-1}\end{array}$ & 87300 & 237200 & 149900 & 2.71 \\
\hline $\begin{array}{l}\mathrm{T}_{6} \text { : Seed treatment with Vitavax power @ } 0.2 \% \\
\text { + Difenoconazole 25EC @ } 0.6 \mathrm{ml} \mathrm{l}^{-1}\end{array}$ & 90300 & 254400 & 164100 & 2.82 \\
\hline $\begin{array}{l}\mathrm{T}_{7} \text { : Seed treatment with Vitavax power @ } 0.2 \% \\
\text { + Mancozeb 75WP @ } 2.5 \mathrm{~g} \mathrm{I}^{-1}\end{array}$ & 85200 & 238800 & 153600 & 2.80 \\
\hline$T_{8}:$ Control (No chemical treatment) & 80000 & 152000 & 72000 & 1.90 \\
\hline
\end{tabular}

Fig.1 Efficacy of fungicides on bulb yield and percentage diseases index in onion (Pooled data for two years)

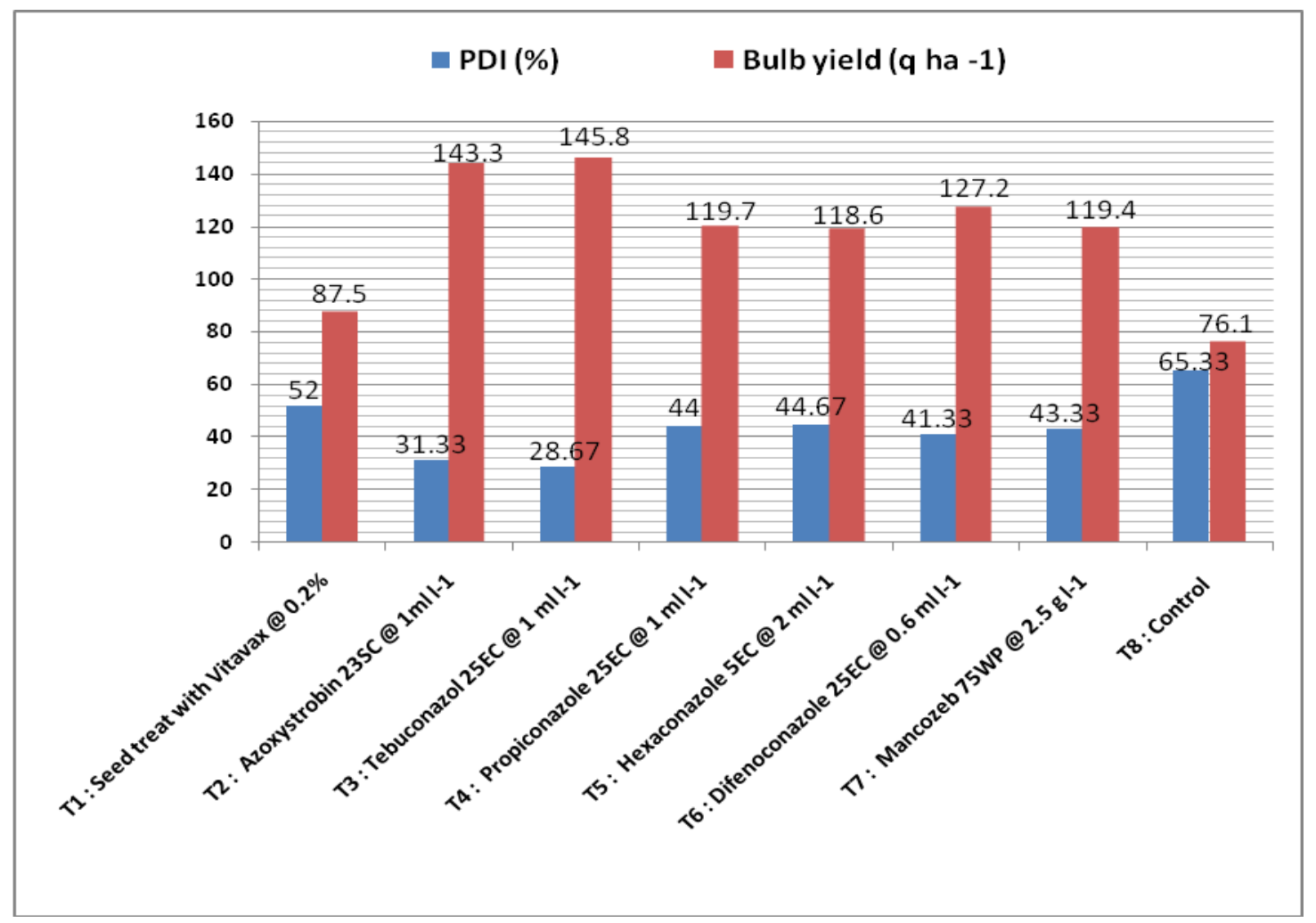


Maximum bulb yield of $145.8 \mathrm{q} \mathrm{ha}^{-1}$ was recorded in plots treated with Tebuconazol 25 EC @ $1 \mathrm{ml} \mathrm{l}^{-1}$, which was statistically at par with Azoxystrobin 23 SC @ 1 $\mathrm{ml} \mathrm{l}^{-1}$ having bulb yield of $143.3 \mathrm{q} \mathrm{ha}^{-1}$. The minimum bulb yield of $76.1 \mathrm{q} \mathrm{ha}^{-1}$ was recorded in control plot. The increase in bulb yield in Tebuconazol 25EC @ $1 \mathrm{ml} \mathrm{l}^{-1}$ treated plot was $91.59 \%$ over the control.

The present findings are in agreement with the observation made by Arunkumar et al., (2016) who reported that application of $0.1 \%$ Tebuconazole 25EC and $0.1 \%$ Azoxystrobin $23 \mathrm{SC}$ is very effective in managing purple blotch disease of onion. Excellent performance of Tebuconazole $25 \mathrm{EC}$ in controlling purple blotch disease of onion was reported earlier by Yadav et al., (2017), Aujila et al., (2013), Aujila et al., (2010), Deshmukh et al., (2007) and Bhatia and Chahal (2014). Bachkar et al., (2018) reported that Azoxystrobin 25SC and Tebuconazole 25EC are most effective fungicides against purple blotch disease of onion. Similarly, the present findings are in agreement with the results reported by Gupta et al., (2012) who observed that systemic fungicides Tebuconazole $25 \%$ EC at $0.1 \%$ and Azoxystrobin $23 \mathrm{EC}$ at $0.15 \%$ effectively controlled purple blotch disease of Garlic.

The data on economics of different treatments (Table 2) revealed that higher net returns of Rs. 2,01,100 $\mathrm{ha}^{-1}$ in the treatment Tebuconazol 25 EC @ $1 \mathrm{ml} \mathrm{l}^{-1}$ was recorded which was followed by Azoxystrobin 23 SC @ $1 \mathrm{ml} \mathrm{l}^{-1}$ (Rs. 1,95,400 ha ${ }^{-1}$ ). Application of Tebuconazol 25 EC@ $1 \mathrm{ml} \mathrm{l}^{-1}$ recorded the maximum B:C ratio (3.22) followed by Azoxystrobin $23 \mathrm{SC} @ 1 \mathrm{ml} \mathrm{l}^{-1}$ with 3.14.

It can be concluded from the two years experiment that the purple blotch disease of onion can be effectively and economically controlled with use of seed treating chemicals like vitavax powder@0.2\% along with the foliar spray of Tebuconazol25 EC @ $1 \mathrm{ml}^{-1}$. This treatment recorded maximum bulb yield of $145.8 \mathrm{q} \mathrm{ha}^{-1}$ which was $91.59 \%$ more than the untreated plot (76.1 q ha' ${ }^{-1}$.

\section{Acknowledgement}

We gratefully acknowledge the Orissa University of Agriculture and Technology, Odisha, India for the research facilities provided to carry out the experiment.

\section{References}

Anonymous. 2013. Odisha Agriculture Statistics, Director of Agriculture and Food Production, Odisha. pp. 70.

Arunkumar, K.T., Satyanarayan, C. and Anandkumar, V. 2016. Varietal reaction of onion cultivars against Alternaria porri causing purple blotch and its management. The Bioscan. 11(4): 29252929.

Aujila, I.S., Amrate, P.K., Kumar, P. and Thind, T.S. 2013. Efficacy of some new fungicides in controlling purple blotch of onion under Punjab condition. Plant Disease Research. 28: 171-173.

Aujila, I.S., Goswami, S., Thind, T.S., Raheja, S. and Kumar, P. 2010. Relative effectiveness of fungicides in controlling purple blotch of onion seed crop. Plant Disease Research. 25:73-74.

Bachkar, C.B., Bhalekar, M.N. and Pawar, S.A. 2018. Control of Alternaria porri causing purple blotch of onion during Kharif season. J. Allium Research. 1(1):57-59.

Bhatia, J.N. and Chahal, D. 2014. Studies on effectiveness of certain new fungicides in controlling Stemphylium blight of onion seed crop. Agric. Sci. Digest. 34:237-239. DOI: 10.5958/09760547.2014 .01011 .8

Deshmukh, V.S., Dhruj, I.U. and Chavan, 
R.V. 2007. Chemical control of purple blotch (Alternaria porri) (Ellis) Cif. of onion. Plant Disease Research. 22: 3436.

FAOSTAT, 2018. Website (http://faostat3.fao.org/home/E) accessed on $13^{\text {th }}$ January, 2019.

Gupta, R.P., Srivastava, K.J. and Pandey, U.B. 1994. Diseases and insect pests of onion in India. Acta Horticulture. 358: 365-369.

Gupta, R.C., Pandey, N.K. and Gupta, R.P. 2012. Management of purple blotch (Alternaria porri) disease of garlic (Allium sativum L.) In: Abstract, IV National symposium on plant protection in horticultural crops: Emerging challenges and sustainable pest management organized at Indian Institute of Horticultural Research, Bengaluru held on 25-28 April, pp. 115.
Compendium of Onion and Garlic Diseases and pests. $\mathrm{II}^{\text {nd }}$ Ed. APS Press. St. Paul. MN. USA.

Sharma, S.R. 1986. Effect of fungicidal sprays on purple blotch and bulb yield of onion. Indian Phytopath. 39 (1): 7882.

Wheeler, B.E.J. 1969. An introduction to plant diseases. John Willey and Sons Ltd. London, 301.

Yadav, P.M., Rakholiya, K.B. and Pawar, D.M. 2013. Evaluation of bio agents for management of the onion purple blotch and bulb yield loss assessment under field conditions. The Bioscan 8(4):1295-98.

Yadav, R.K., Singh, A., Jain, S. and Dhatt, A.S. 2017. Management of purple blotch complex of onion in Indian Punjab. Int. J. Appl. Sci. Biotechnol. Vol 5(4): 554-565.

Schwartz, H.F. and Mohan, S.K. 2008.

\section{How to cite this article:}

Niranjan Mandi, Bhabani Shankar Nayak, Bibhuti Bhusan Sahoo, Ganesh Prasad and Chandramani Khanda. 2020. Efficacy of Novel Fungicides against Purple Blotch in Onion (Allium cepa L.) in the Western Undulating Zone of Odisha, India. Int.J.Curr.Microbiol.App.Sci. 9(04): 1970-1976. doi: https://doi.org/10.20546/ijcmas.2020.904.235 